\title{
Niezrealizowane projekty odbudowy kościoła w Oruni autorstwa gdańskiego architekta miejskiego Carla Samuela Helda ${ }^{1}$
}

\author{
DOI: https://doi.org/10.26881/porta.2020.19.13
}

Zajęcie Gdańska przez Królestwo Prus w 1793 r., obok przemian natury politycznej czy gospodarczej, przyniosło także zasadnicze zmiany w funkcjonowaniu lokalnej sceny architektonicznej. Odtąd gdańskie sprawy budowlane stały się częścią złożonej struktury administracyjnej, na której szczycie stał urząd berliński². W wymiarze lokalnym najważniejszą rolę pełnił miejski radca budowlany (Stadtbaurath) ${ }^{3}$.

Stanowisko to objął w 1794 r., jako pierwszy w Gdańsku, wrocławianin Carl Samuel Held $(1766-1845)^{4}$. Sprawował on swój urząd przez cztery kolejne dekady

1 Tekst powstał z inspiracji Pani prof. dr hab. Małgorzaty Omilanowskiej, która podczas jednego z seminariów doktorskich zasugerowała, że prezentowane przeze mnie projekty kościoła w Oruni zasługują na omówienie w osobnym artykule. Po latach, korzystając z wyjątkowej okazji jubileuszu urodzin Pani Profesor, pozwoliłam sobie na napisanie tego tekstu, będącego poszerzeniem ustaleń zawartych w pracy doktorskiej. Liczę, że jego lektura sprawi Pani Profesor przyjemność, a także będzie kolejnym wkładem do badań nad dziewiętnastowieczną architekturą bliskiego Pani sercu Gdańska.

2 Mowa tu o Wyższym Departamencie Budowlanym (Oberbaudepartement), przekształconym w 1804 r. w Królewską Techniczną Wyższą Deputację Budowlaną (Königliche Technische Oberbaudeputation). Na temat organizacji budownictwa publicznego w Prusach w XIX w. zob. m.in. P. Krause, Die Entwicklung der preußischen Hochbauverwaltung, „Zentralblatt der Bauverwaltung" 1920, nr 47, s. 298-301; Hans-Werner Zawisla, Das öffentliche Bauwesen Preussens im 19. Jahrhundert und sein Einfluss auf die allgemeine staatliche Entwicklung, Aachen 1983; Eckhard Bohlenz, Vom Baubeamten zum freiberuflichen Architekten. Technische Berufe im Bauwesen. Preußen/Deutschland, 1799-1931, Frankfurt-New York 1991; Reinhart Strecke, „Dem Geist der neuen Verfassung gemäß”. Vom Oberbaudepartment zur Oberbaudeputation [w:] Aus der Arbeit des Geheimen Staatsarchivs Preußischer Kulturbesitz, Hg. Jürgen Kloosterhuis, Berlin 1996, s. 75-102.

3 Uprawnienia i obowiązki miejskiego architekta były bardzo szerokie. Pełnił on nadzór nad istniejącymi budynkami publicznymi, prowadził nowe inwestycje i prace naprawcze. Odpowiadał za drogi, mosty, składy materiałów budowlanych, wodociągi, kanalizację i ochronę przeciwpożarową miasta. Wykonywał rysunki inwentaryzacyjne, sporządzał plany gruntów i mapy. Ponadto zatwierdzał do realizacji i kontrolował przebieg prywatnych inwestycji. Więcej o obowiązkach Helda zob. Waldemar Krause, Das Danziger Theather und sein Erbauer Carl Samuel Held, Danzig 1936, s. 37-38; zob. też Erich Keyser, Die Baugeschichte der Stadt Danzig, Köln-Wien 1972, s. 392.

4 Główne źródło wiedzy na temat architekta stanowi przedwojenna dysertacja autorstwa Waldemara Krause, Das Danziger Theather und sein Erbauer Carl Samuel Held. Na jej podstawie 
Magdalena i odegrał znaczącą rolę w dziejach porozbiorowej architektury gdańskiej, przyStarega czyniając się do upowszechnienia w Gdańsku form klasycystycznych. Największą popularność przyniósł mu niewątpliwie jego wczesny projekt - teatr na Targu Węglowym (1799-1801) ${ }^{5}$, znakomita realizacja utrzymana w duchu tzw. klasycyzmu rewolucyjnego ${ }^{6}$. Istotny wpływ na gdańskiego urzędnika miała twórczość jednego z najwybitniejszych architektów pruskich tego czasu, Carla Gottharda Langhansa (1732-1808), u którego Held zaczął pobierać nauki w wieku dwunastu lat ${ }^{7}$. Architekci współpracowali ze sobą również po przenosinach do Berlina, gdzie w 1788 r. otrzymali zatrudnienie w Królewskim Wyższym Urzędzie Budowlanym (Oberhofbauamt) ${ }^{8}$. Held miał okazję współpracować z Langhansem przy największych realizacjach mistrza: teatrze anatomicznym Wyższej Szkoły Weterynaryjnej (1789-1790), Bramie Brandenburskiej (1788-1791) czy gmachu opery przy Unter den Linden w Berlinie (1787) ${ }^{9}$. Być może to właśnie rekomendacja

powstały powojenne biogramy polskie, zob. Stanisław Łoza, Architekci i budowniczowie w Polsce, Warszawa 1954, s. 112; Stanisław Gierszewski, Słownik biograficzny Pomorza Nadwiślańskiego, Gdańsk 1994, t. 2, s. 180. Postać Helda pojawia się także w wydawnictwach popularnonaukowych, zob. Mirosław Gliński, Ludzie dziewiętnastowiecznego Gdańska, Gdańsk 1994, s. 42. Próbę naszkicowania przemian Gdańska przełomu wieków w kontekście twórczości urzędnika podjął w swoim eseju Jacek Bielak, Budowniczy miejski Carl Samuel Held i próby modernizacji Gdańska na przełomie XVIII/XIX wieku [w:] Gdańsk i okolice 1793-1914. Miasto - ludzie - wydarzenia w rysunku i grafice, red. Wojciech Bonisławski, Aleksander Baliński, Gdańsk 2014, s. 54-63.

5 Projekt teatru sporządzony dla Towarzystwa Akcyjnego powstał w ramach prywatnej praktyki architekta. Budynek ten należy do najbardziej znanych gdańskich realizacji tego czasu, zob. m.in. Krause, Das Danziger Theather..., s. 11-27; Andrzej Prusiewicz, Trzy teatry na Targu Węglowym 1801-1935-1967 [w:] 200 lat teatru na Targu Wegglowym w Gdańsku, red. Jan Ciechowicz, Gdańsk 2004, s. 57-68; Robert Hirsch, Architektura teatrów na Targu Weglowym w Gdańsku [w:] 200 lat teatru na Targu Weglowym..., s. 47-56; zob. też Ewelina Damps, Historia Teatru Miejskiego w Gdańsku (1801-1841), Gdańsk 2015.

6 Więcej na ten temat zob. Klaus-Jan Philipp, Randez-vous bei Boullée. Pariser Architektur im Urteil deutscher Architekten um 1800 [w:] Deutsche Baukunst um 1800, Hg. Reinhard Wegner, Köln 2000, s. 109-128 (tam dalsza literatura). Odpowiadające temu zjawisku pojęcie „stylu około 1800 roku" upowszechnił architekt Paul Mebes, Um 1800. Architektur und Handwerk im letzten Jahrhundert ihrer traditionellen Entwicklung, München 1908; zob. też Irma Kozina, Styl około 1800. Styl narodowy czy nowa rzeczywistość w architekturze Górnego Śląska? [w:] Nacjonalizm w sztuce i historii sztuki 1789-1950, red. Dariusz Konstantynów, Robert Pasieczny, Piotr Paszkiewicz, Warszawa 1998, s. 171-182.

7 Krause, Das Danziger Theather..., s. 29. Więcej na temat twórczości architekta zob. Jerzy Krzysztof Kos, Carl Gotthard Langhans 1732-1808. Architekt z Kamiennej Góry, Kamienna Góra 2007; idem, Der Weg nach Berlin... Carl Gotthard Langhans' Tätigkeit in Schlesien 1760-1808 [w:] Deutsche Baukunst um 1800, Hg. Reinhard Wegner, Köln 2000, s. 65-92; Friedhelm Grundmann, Carl Gotthard Langhans (1732-1808). Lebensbild und Architekturführer, Würzburg 2007; Regulus Velin, Der Baumeister des Brandenburger Tores. Historiographisches über den Architekten Carl Gotthard Langhans, Berlin 1983.

$8 \quad$ Na życzenie króla Prus Fryderyka Wilhelma II Langhans objął w Berlinie stanowisko dyrektora tegoż urzędu.

9 Walther Th. Hinrichs, Carl Gotthard Langhans. Ein schlesischer Baumeister 1733-1808, Strassburg 1909, s. 56; Eckart Rüsch, Baukonstruktion zwischen Innovation und Scheitern. Verona, Langhans, Gilly und die Bohlendächer um 1800, Petersberg 1997, s. 273. 
złożona przez Langhansa zaważyła na decyzji ówczesnego nadprezydenta prowincji Prus Zachodnich, Friedricha Leopolda von Schröttera (1743-1815), o zatwierdzeniu kandydatury Helda na urząd gdańskiego budowniczego ${ }^{10}$.

Kadencja Helda przypadła na wyjątkowo burzliwy okres w dziejach Gdańska. Mimo że przechodzenie miasta spod jednego panowania pod drugie, a także dwa fatalne w skutkach oblężenia nie sprzyjały stabilizacji i rozwojowi, w zakresie prac budowlanych na pewne ożywienie wpływała konieczność odbudowy Gdańska po powstałych wówczas zniszczeniach. To właśnie na tym zadaniu koncentrowała się uwaga Helda po odbiciu miasta $\mathrm{z}$ rąk francuskich przez Królestwo Prus w 1814 r. Do szczególnie interesujących przykładów takich inwestycji należy kościół ewangelicki znajdujący się na terenie podgdańskiej wsi Orunia (Ohra) ${ }^{11}$. W 1813 r., wraz z wycofywaniem się z miasta wojsk napoleońskich, spaleniu uległ wykorzystywany przez luteran dom modlitwy ${ }^{12}$.

Do tej pory uwagę badaczy zajmujących się kościołem oruńskim przykuwał jedynie zrealizowany projekt jego odbudowy ${ }^{13}$. Nowe światło na proces dochodzenia do tej wersji rzucają zachowane w gdańskim Archiwum Państwowym projekty sygnowane przez Helda. Dwa z nich stanowią część dokumentacji Konsystorza Ewangelickiego w Gdańsku ${ }^{14}$, kolejne, w postaci luźnych rysunków projektowych, znajdują się w zespole gdańskiej Rejencji obejmującej plany

10 Krause, Das Danziger Theather..., s. 28.

11 Orunia leżała poza terytorium administracyjnym miasta Gdańska, należała jednak, jak niektóre inne wsie podmiejskie, do ustalonego w 1814 r. terenu miejskiego okręgu policyjnego. Jako teren podlegający Dyrekcji Policji (Königliches Polizei-Direktorium) był on również pod kontrolą działającej w jej obrębie Policji Budowlanej (Staatliches Baupolizeiamt zu Danzig), na której czele stał architekt miejski, zob. Max Wessel, Die Organisation der Polizei in der Stadt Danzig und in ihrem Hafen nach Einverleibung derselben in die preußische Monarchie, Danzig 1905, s. 24. Więcej o urzędzie Policji Budowlanej w Gdańsku zob. Zofia Maciakowska, Wojciech Szymański, Akta Policji Budowlanej jako materiał do studiów nad gdańską kamienica mieszczańska od średniowiecza do początku XIX wieku [w:] Dom w mieście średniowiecznym i nowożytnym, red. Bogusław Gediga, Wrocław 2004, s. 249-276; eidem, Dokumentacja Urzędu Policji Budowlanej w Gdańsku jako źródło do badań nad dawnymi kamienicami [w:] Studia i materiały do dziejów domu gdańskiego, cz. 1, red. Edmund Kizik, Gdańsk 2009, s. 207-223; Ludwig von Rönne, Heinrich Simon, Die Bau-Polizei des Preussischen Staates. Eine systematisch geordnete Sammlung aller auf dieselbe Bezug habenden gesetzlichen Bestimmungen, Breslau 1846, s. 2-3.

12 Zamieszkujący Orunię luteranie korzystali z własnej kaplicy od drugiej połowy XVI w., zob. Ernst Wilhelm Waage, Ausführliche Geschichte Ohra's eines Dorfes im Danziger Landraths-Kreise, Regierungsbezirks Danzig, Danzig 1859, s. 5. Więcej o historii kościoła zob. John Muhl, Die Kirche und Schule in Ohra, „Weichselland” 1942, nr 41, s. 40-45; Jerzy Samp, Orunia, Stare Szkoty i Lipce, Gdańsk 2005, s. 93-115. Po zniszczeniu domu modlitwy mieszkańcy Oruni i okolic wykorzystywali na cele sakralne leżący w pobliskich Lipcach zajazd Trzy Świńskie Głowy (Drei Schweinsköpfe), zob. Agathon Harnoch, Chronik und Statistik der evangelischen Kirchen in den Provinzen Ost- und Westpreussen, Neidenburg 1890, s. 393.

13 Notę dotyczącą obiektu zamieściła w swojej obszernej monografii poświęconej Karlowi Friedrichowi Schinklowi Eva Börsch-Supan, Karl Friedrich Schinkel. Die Provinzen Ost- und Westpreußen und Großherzogtum Posen, München-Berlin 2003, s. 287-289.

14 Archiwum Państwowe w Gdańsku [dalej: APGd], Konsystorz Ewangelicki w Gdańsku 1816-1944 [dalej: KEG], sygn. 977/3044. 
Magdalena i mapy ${ }^{15}$. Łącznie zachowało się aż osiem wariantów projektów kościoła, które Starega poprzedziły wersję finalną. Dwa pierwsze projekty zostały sporządzone w $1816 \mathrm{r}$., kolejne propozycje, odmienne formalnie, Held przygotował w latach 1818-1819.

Pierwszy projekt Helda z 8 czerwca 1816 r. był propozycją spójną i przemyślaną, przygotowaną z dużą starannością (il. 1). Architekt przewidywał budowę kościoła na planie prostokąta, $\mathrm{z}$ dostawioną od zachodu wieżą na rzucie kwadratu oraz półkolistym prezbiterium. Wieżę miała przykrywać charakterystyczna kopuła, korpus główny miał być kryty dachem dwuspadowym, a prezbiterium - dachem krążynowym. W ścianach bocznych architekt rozmieścił duże półkoliście zamknięte okna. Podobnie opracowane zostały wejścia: główne w wieży oraz dodatkowe w elewacji bocznej, które otrzymały półkoliste nadświetla. Nad wejściem bocznym, nad linią okapu Held zaprojektował szeroki, podwójny szczyt, wypełniony płaskorzeźbioną dekoracją. Oprawy zewnętrznej budynku dopełniały pokryte boniowaniem elewacje oraz zegary umieszczone na wieży. Wnętrze miało być trójnawową pseudobazyliką. Nawę główną zamykało drewniane sklepienie pseudokolebkowe, a nawy boczne - płaski strop. We wnętrzu Held rozplanował empory wsparte na drewnianych filarach oraz chór organowy podtrzymywany przez dwie kolumny. Na osi prezbiterium zastosował powtarzające się w kolejnych projektach rozwiązanie, niespotykane dotąd na gruncie gdańskim, w postaci kazalnicy poprzedzonej ołtarzem w formie stołu ofiarnego (Kanzelaltar) ${ }^{16}$. Architekt wycenił koszty budowy na ponad 18431 talarów, co uznano za kwotę zbyt wysoką ${ }^{17}$.

Forma drugiej propozycji z 6 grudnia tego samego roku była znacznie skromniejsza ze względu na założenie mniejszego budżetu (il. 2). Held zdecydował się na maksymalną redukcję detalu i uproszczenie bryły poprzez rezygnację z absydy. Pozostał jednak przy murowanych ścianach i wieży, która w tym wydaniu była niska i masywna. Mieściła proste wejście główne, nad którym przebito półkoliste okno. Podobne wejścia umieszczono w ścianach bocznych kościoła. Korpus główny i wieżę miały przykryć niskie dachy dwuspadowe, a wnętrza doświetlać okna zamknięte półkoliście, ale o mniejszych niż poprzednio wymiarach. Architekt zaprojektował wnętrze jednonawowe, z emporą na krótszym boku, wspartą na dwóch kolumnach. Proste, kubiczne kształty budynku tworzyły właściwie bezstylową formę. Tym razem kosztorys inwestycji opiewał na kwotę 10459 talarów $^{18}$.

15 APGd, Rejencja w Gdańsku. Plany i mapy 1713-1911 [dalej: RGPM], sygn. 18/1614. O istnieniu tych projektów wspomina Jacek Bielak, Tradycjonalizm w stużbie państwa. Szkic z dziejów nowego gmachu Gdańskiego Gimnazjum Akademickiego [w:] Tradycjonalizm i neotradycjonalizm w sztuce XIX i XX wieku na Pomorzu, red. Józef Tarnowski, Roman Nieczyporowski, Gdańsk 2012, s. 99.

16 Rozwiązanie tego typu, aczkolwiek w znacznie bardziej oszczędnej formie, znalazło zastosowanie w gdańskim kościele mennonitów autorstwa mistrza budowlanego Brettschneidera i mistrza ciesielskiego Fuchsa. Kościół powstał w latach 1818-1819 na terenie Czarnego Morza, u stóp Biskupiej Górki.

17 APGd, KEG, sygn. 977/3044, s. 3 i n.

18 Łącznie z budową domu pastora i lokum dla grabarza koszt miał wynieść 13225 talarów, zob. ibidem, s. 11. 


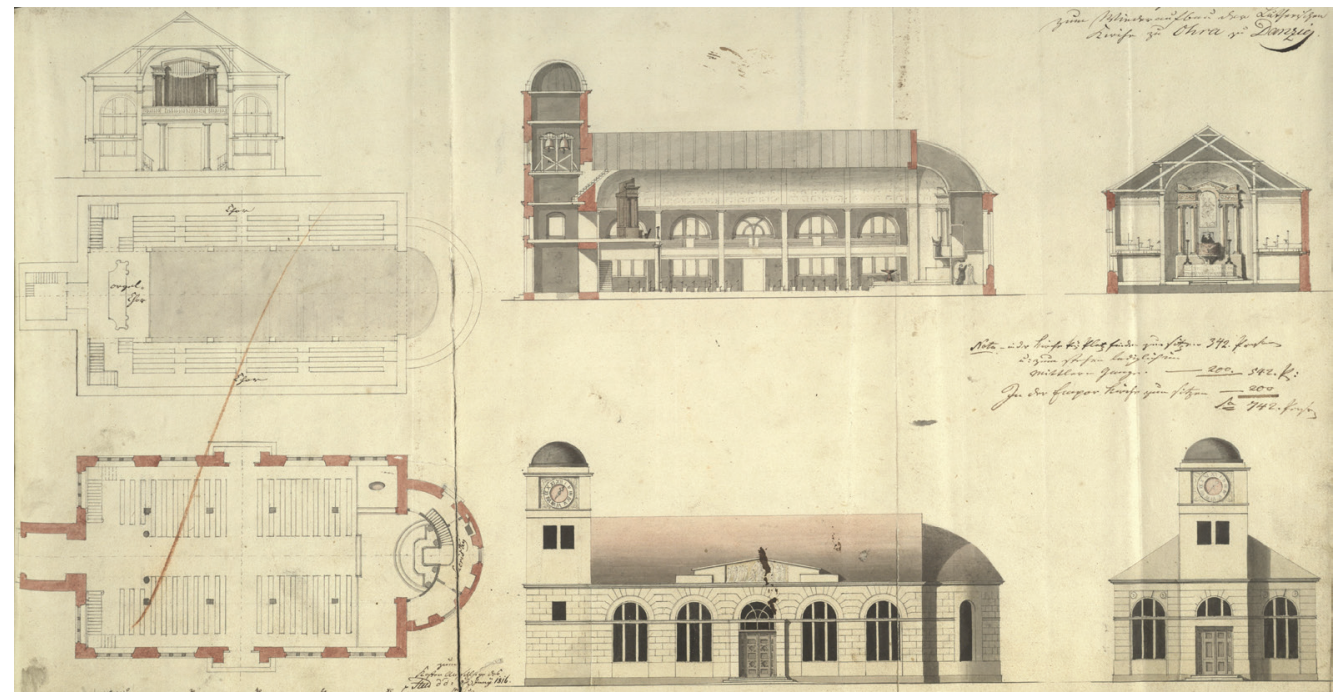

Il. 1. Carl Samuel Held, projekt kościoła w Oruni, 8 czerwca 1816, APGd, KEG, sygn. 977/3044

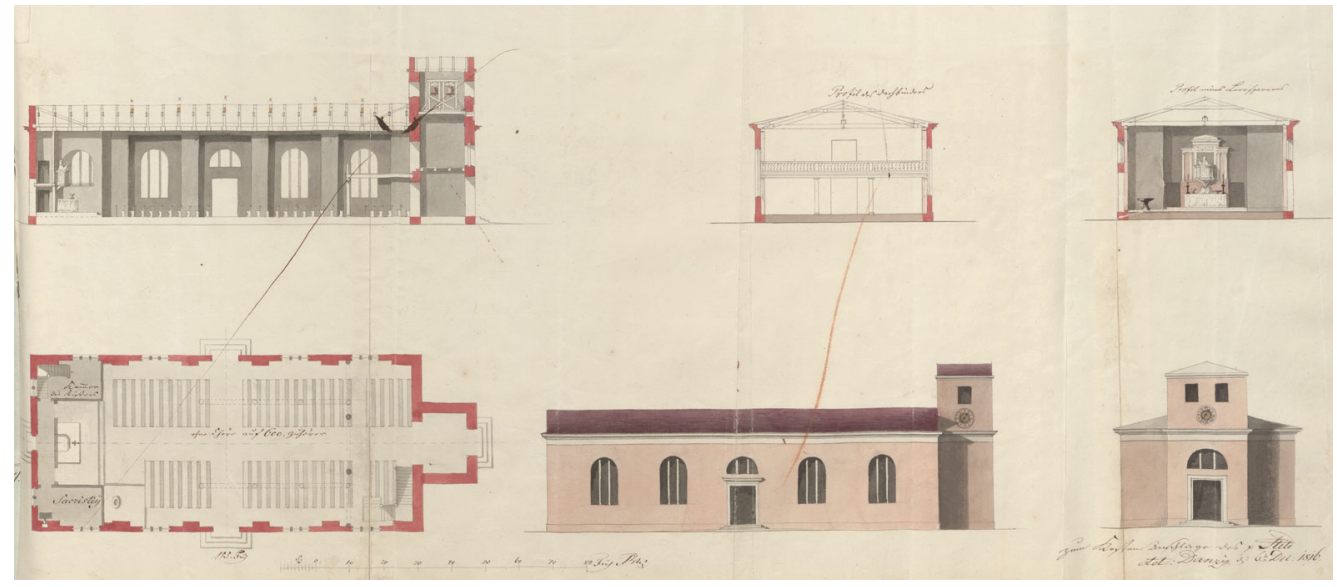

Il. 2. Carl Samuel Held, projekt kościoła w Oruni, 6 grudnia 1816, APGd, KEG, sygn. 977/3044

Brak odgórnych zaleceń dotyczących kwestii formalnych czy ekonomicznych sprawił, że dwa pierwsze projekty Held mógł opracować zgodnie z własnymi preferencjami artystycznymi. W efekcie powstały jedne z najciekawszych propozycji w całym jego architektonicznym dorobku. Architekt odwołał się przy tym do stałych w jego twórczości zabiegów, takich jak operowanie prostą, geometryczną bryłą, oszczędna dekoracja czy upodobanie do stosowania motywów owalnych. Rozwiązania te w pełni wpisywały się w tendencje stylowe panujące na przełomie XVIII i XIX w. w Królestwie Prus.

Po przestoju spowodowanym niemożnością uzyskania środków na budowę Held powrócił do tematu odbudowy oruńskiego kościoła w połowie 1818 r. Bodźcem 
do kontynuowania prac było złożenie przez Fryderyka Wilhelma III deklaracji

wsparcia finansowego inwestycji. Król poparł wniosek o wsparcie przedsięwzięcia kwotą 13000 talarów, suma ta wynikała z wcześniejszej wyceny dokonanej przez Helda ${ }^{19}$. Nowe okoliczności wpłynęły na zmianę oprawy stylowej obiektu. Architekt po raz pierwszy w swojej karierze sporządził projekty odwołujące się do form gotyckich. Powielały one użyty w najwcześniejszej propozycji model murowanego kościoła $\mathrm{w}$ formie trójnawowej pseudobazyliki z wieżą. Tym razem Held wprowadził ostrołukowe zamknięcia okien i wejść, a także zrezygnował z tynkowania ścian zewnętrznych na rzecz pozostawienia ceglanego lica murów. Pierwszy nawiązujący do gotyku wariant charakteryzował się wydatną rozetą umieszczoną nad wejściem głównym oraz wieżą ze sterczynami i wysokim hełmem (il. 3). We wnętrzu Held ponownie zaplanował sklepienie pseudokolebkowe, w tym przypadku przekrywające każdą z trzech naw. Ciężar sklepień oraz konstrukcji dachu miał być oparty na filarach we wnętrzu oraz systemie zewnętrznych przypór. $\mathrm{W}$ nawach bocznych budowli projektant rozmieścił empory, z kolei prezbiterium od reszty wnętrza miało oddzielać bogato zdobione lektorium, na którego osi architekt zaprojektował Kanzelaltar.

Wariant drugi zakładał wykorzystanie zachowanych fundamentów dawnego kościoła, co poskutkowało wprowadzeniem szerokiego, trójbocznego prezbiterium (il. 4). Kościół miał być niższy niż w pierwszym wariancie. Zamiast sklepień pseudokolebkowych Held zaproponował płaskie drewniane stropy, nie rezygnując przy tym z przypór, które nadal miały stanowić istotny element zewnętrznej oprawy obiektu. W tej opcji wyróżniono - poprzez znacznie bogatszą oprawę - wejście boczne, które zwieńczono wysokim, schodkowym szczytem z przepruciem nad linią okapu. Neogotycka dekoracja wieży została tu zredukowana na rzecz stylizowanych, uproszczonych form. Kwota finalna na kosztorysie przedłożonym 6 lipca 1818 r. wynosiła 20802 talarów, dalece odbiegając od przyjętych założeń20.

Trafność rozwiązań zastosowanych w pierwszych neogotyckich projektach Helda jest dyskusyjna. Wątpliwości może budzić przede wszystkim niemające praktycznego uzasadnienia okno nad linią okapu czy wprowadzenie półkolistych sklepień. Niestandardowym rozwiązaniem była także rezygnacja z bogatej oprawy wejścia głównego na rzecz portalu bocznego, stanowiąca rozwinięcie koncepcji zastosowanej w projekcie z czerwca $1816 \mathrm{r}$. Trudno też określić, na ile przypory miały pełnić rzeczywistą funkcję konstrukcyjną, a na ile były pozbawionym praktycznego zastosowania elementem neogotyckiego kostiumu.

W październiku 1818 r. Held przedstawił kolejne trzy propozycje, które ograniczały się do rysunków fasady i elewacji bocznej (il. 5). Niestety, projekt pierwszego wariantu, zachowany w gdańskim archiwum, jest niekompletny. 


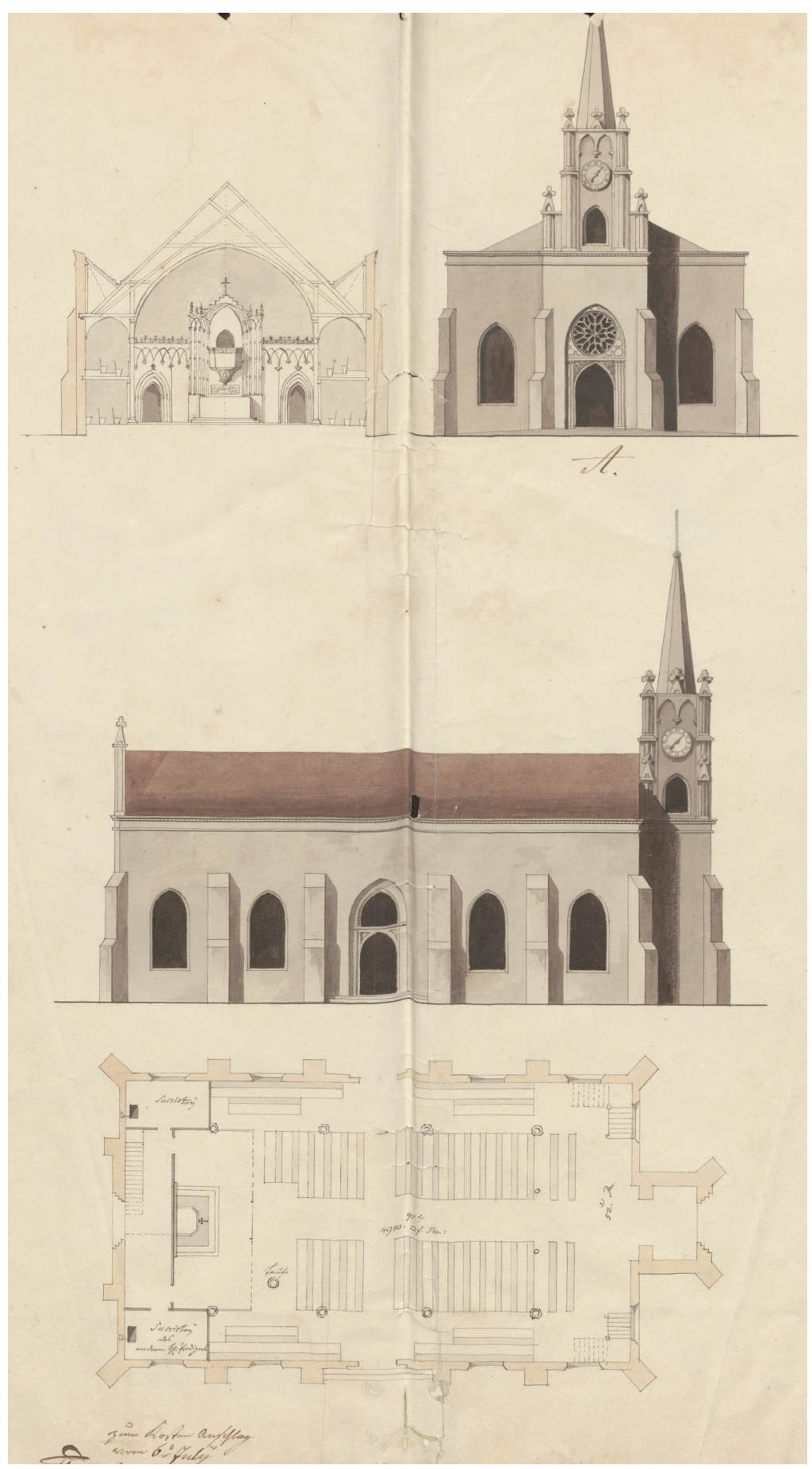

Il. 3. Carl Samuel Held, projekt kościoła w Oruni, czerwiec 1818, wariant pierwszy, APGd, RGPM, sygn. 18/1614 


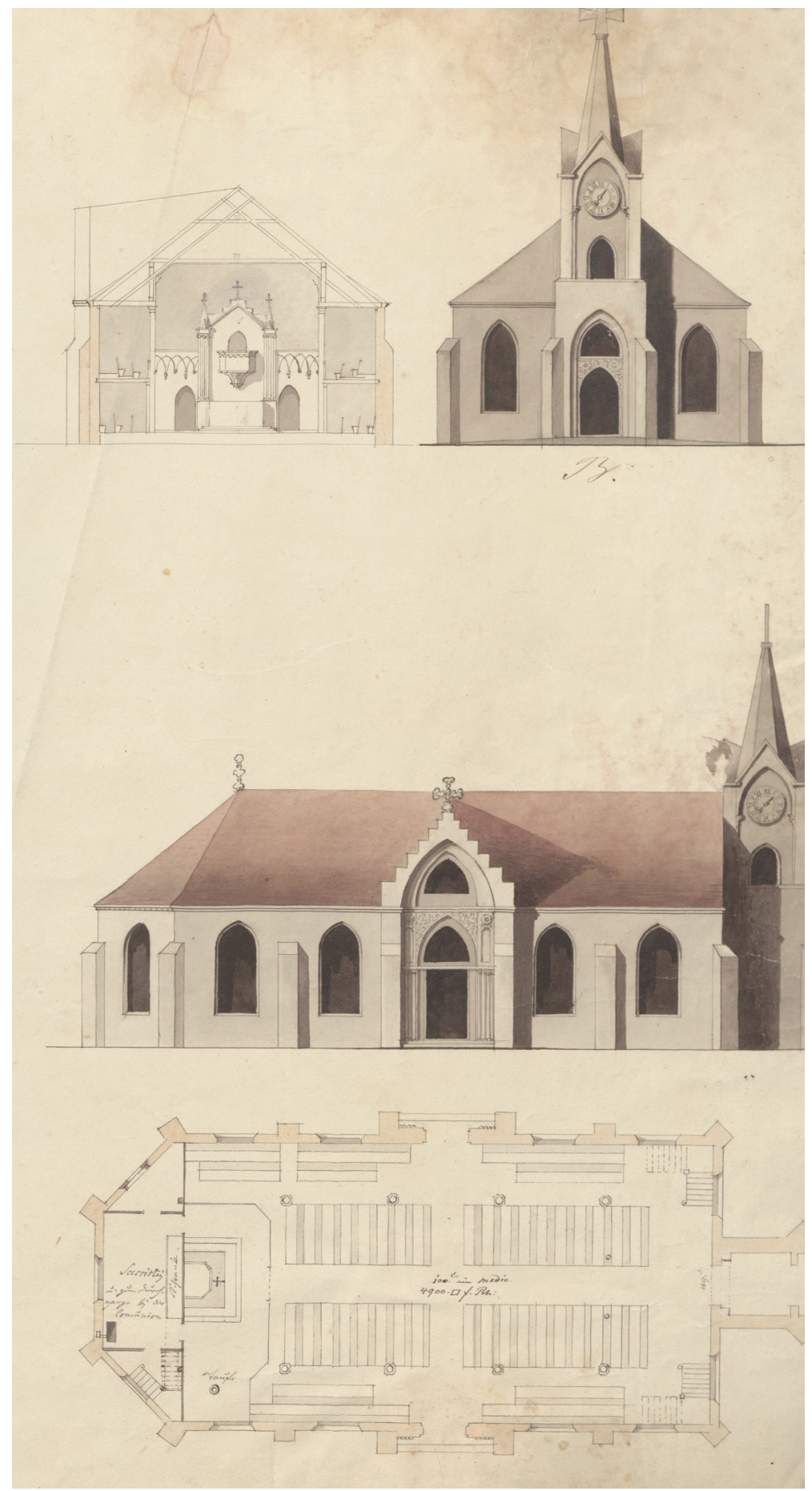

Il. 4. Carl Samuel Held, projekt kościoła w Oruni, czerwiec 1818, wariant drugi, APGd, RGPM, sygn. 18/1614 
Dwa pozostałe zakładały budowę trójnawowej bazyliki. Poszczególne wersje Niezrealiróżnią się od siebie dekoracją oraz proporcjami części frontowej z wieżą, która tym razem została wtopiona $\mathrm{w}$ korpus budowli. $\mathrm{W}$ obu projektach architekt zowane powielił rozwiązanie z przesadnie bogato opracowanym - względem wejścia głównego - portalem bocznym. Doklejony do surowego korpusu budowli, w zestawieniu ze stosunkowo niską wieżą stworzył efekt złego wyważenia całości. Propozycje te zostały wycenione na ponad 22000 talarów ${ }^{21}$.

Przedłożone przez Helda projekty nie mogły spotkać się z pozytywną opinią weryfikujących je urzędników ze względu na znaczne przekroczenie przyjętego budżetu ${ }^{22}$. Wątpliwości budziła także przewidziana przez architekta maksymalna liczba wiernych mogących przebywać w kościele, nieodpowiadająca wymogom gminy $^{23}$. Przedłużające się prace, a także brak obiecanych środków skłoniły kolegium kościelne z Friedrichem Hoene na czele do wystosowania w styczniu 1819 r. pisma do króla. W efekcie środki zostały szybko zadekretowane, a w prace nad powstaniem projektu zaangażowano innych urzędników ${ }^{24}$. Nie powstrzymało to jednak Helda od przedstawienia kolejnej propozycji, ukończonej 29 listopada 1819 r., czyli już po weryfikacji i zatwierdzeniu przez Wyższą Deputację Budowlaną innego projektu ${ }^{25}$.

Ostatnia koncepcja gdańskiego budowniczego w znacznym stopniu różniła się od poprzednich (il. 6). Tym razem próba drastycznego obniżenia kosztów budowy znacząco odbiła się na formie kościoła. Held zamienił ściany murowane na ryglowe, nie przewidując przy tym pokrycia ich tynkiem ${ }^{26}$. Całkowicie zrezygnował też z elementów dekoracyjnych. W efekcie miała powstać prosta, bezstylowa budowla. $\mathrm{W}$ tej propozycji architekt ponownie uwzględnił trójboczne, szerokie prezbiterium, a także powrócił do rozwiązania z dostawioną wieżą pełniącą funkcję dzwonnicy. Trójnawowe, halowe wnętrze, kryte płaskim stropem, zostało wyposażone w trzy empory. Rezygnacja $\mathrm{z}$ detalu pozwoliła projektantowi skupić się na lepszych proporcjach oraz funkcjonalności obiektu.

Neogotyckie projekty Helda stanowią pod wieloma względami ciekawy materiał badawczy. Przede wszystkim są jedynymi w jego twórczości przykładami zastosowania form innych niż klasycystyczne. Zauważalna jest typowa dla gdańskiego budowniczego potrzeba eksperymentowania $\mathrm{z}$ formą, przetwarzania jej i upraszczania. Architekt unikał kopiowania gotowych motywów i nie trzymał się sztywno historycznych wzorców. Jednocześnie jego projekty ujawniają znaczną nieporadność w operowaniu formami gotyckimi. Mimo zastosowania

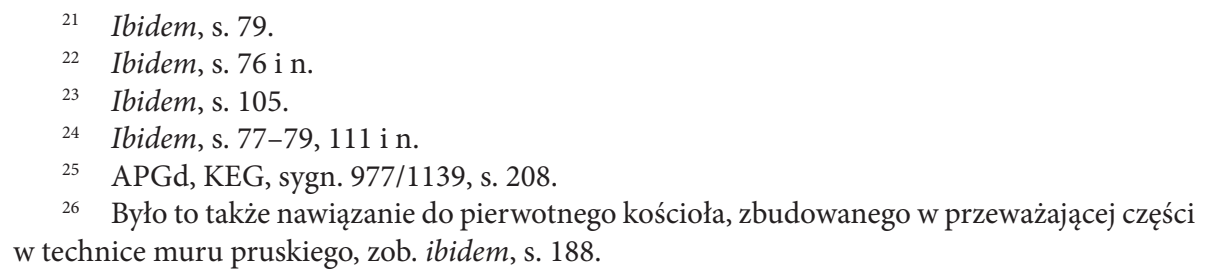




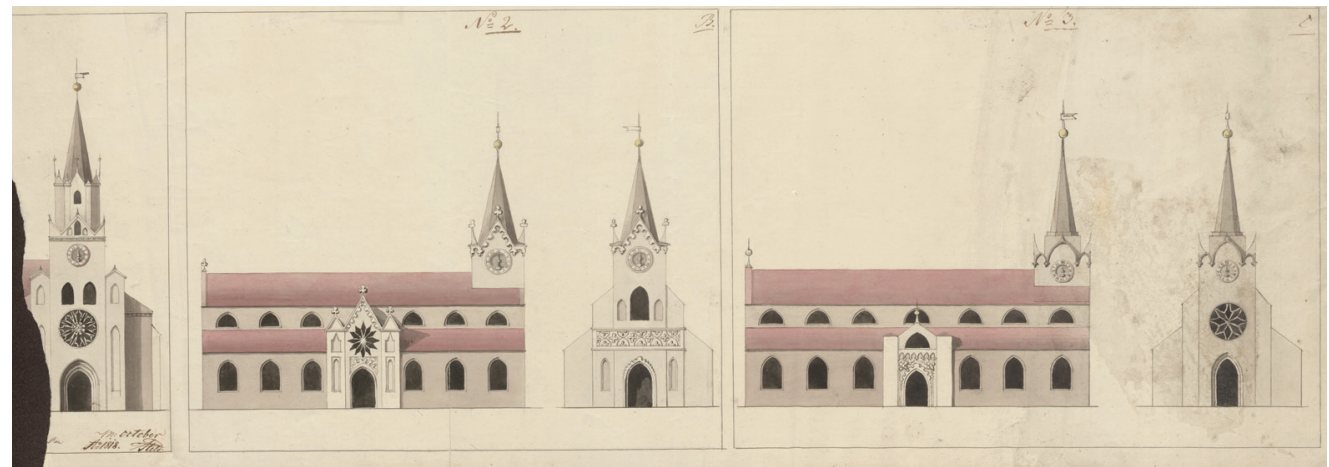

Il. 5. Carl Samuel Held, projekt kościoła w Oruni, październik 1818, trzy warianty, APGd, RGPM, sygn. $18 / 1614$

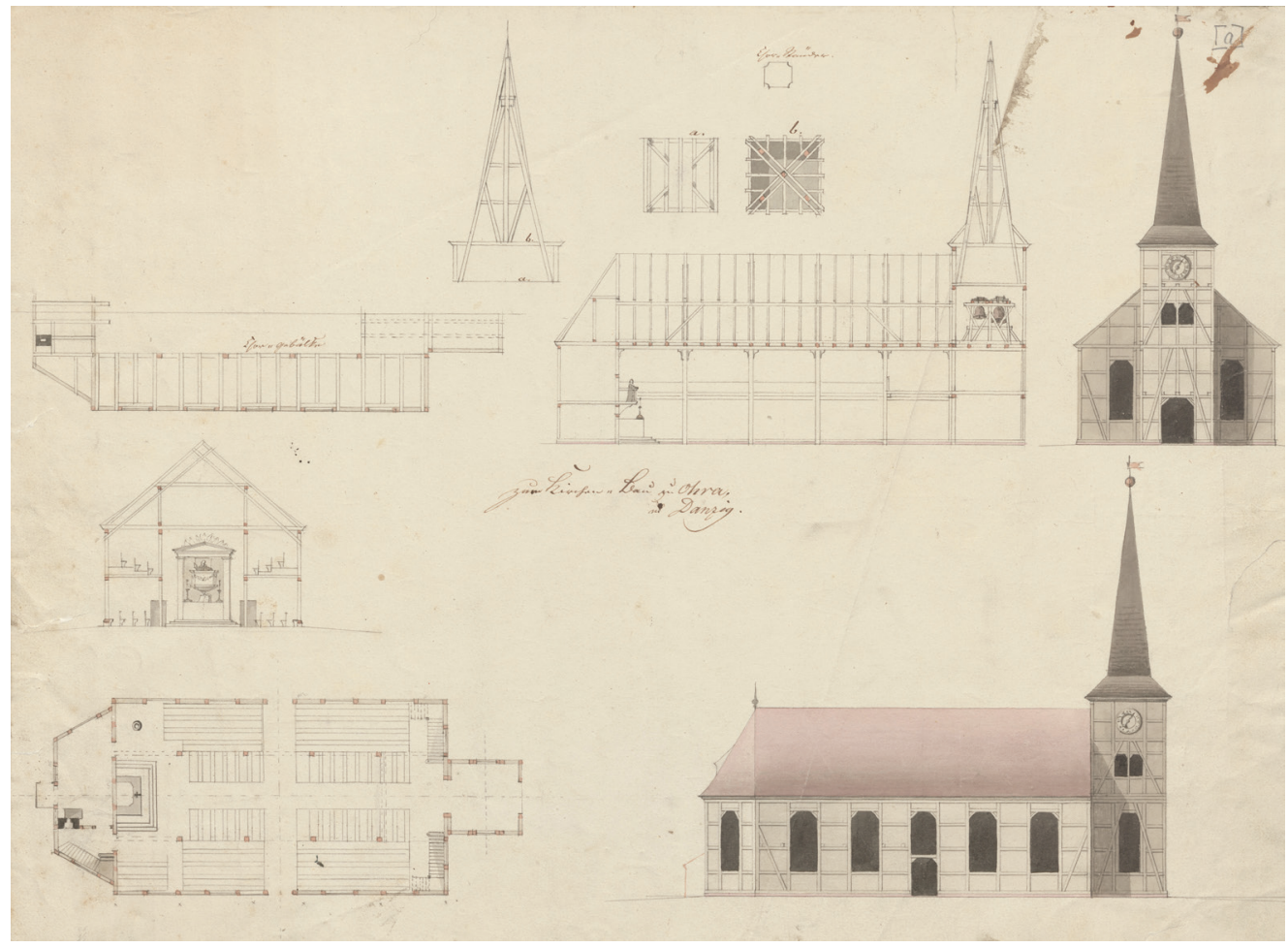

Il. 6. Carl Samuel Held, projekt kościoła w Oruni, listopad 1819, APGd, RGPM, sygn. 18/1614 
w projektowanych kościołach typowych dla tego stylu elementów, takich jak ostre łuki, rozety czy maswerki, propozycje Helda dają dość sztuczny efekt, zdradzając przy tym klasyczne myślenie o bryle.

Brak doświadczenia w operowaniu średniowiecznymi motywami zdaje się wynikać z przebiegu edukacji i kariery architekta. W czasie kształtowania się jego warsztatu architektonicznego obowiązywały rozwiązania klasycystyczne, a realizacje neogotyckie należały do rzadkości. Praca u boku Langhansa stworzyła mu jednak kilka możliwości praktycznego obcowania $z$ formami średniowiecznymi. Wiadomo, że pracował przy powstawaniu gotycyzującej biblioteki w poczdamskim Nowym Ogrodzie (Neuer Garten, 1791)27. W 1791 r. był jednym z dwóch inspektorów budowlanych kierujących pracami przy budowie nowego neogotyckiego hełmu kościoła Mariackiego w Berlinie ${ }^{28}$. Nie ulega jednak wątpliwości, że jego rola w tym procesie ograniczała się do sporządzania rysunków i kontroli nad przebiegiem inwestycji. Formy klasycyzujące były mu zdecydowanie najbliższe - stosował je przez cały okres swojej późniejszej kariery w Gdańskư ${ }^{29}$.

Zagadkę stanowi liczba przygotowanych przez Helda wariantów. O ile dwie pierwsze propozycje wydają się przemyślane, o tyle wątpliwości budzi seria projektów gotycyzujących, powielających podobne motywy. Być może zwielokrotnienie propozycji było próbą rekompensaty przekroczenia założonego budżetu lub dążeniem do sprostania wymogom urzędników weryfikujących projekty. Zapewne nie bez znaczenia były tutaj osobiste aspiracje architekta, którego propozycje w przeszłości niejednokrotnie bywały odrzucane ze względów estetycznych, funkcjonalnych bądź finansowych. Stało się tak zarówno z przygotowanym $\mathrm{w} 1794 \mathrm{r}$. projektem domu pracy (Arbeitshaus) ${ }^{30}$, kąpieliska morskiego w Jelitkowie (1801) ${ }^{31}$, Gimnazjum Akademickiego (1803) ${ }^{32}$, jak i Biblioteki Miejskiej (1805) ${ }^{33}$. Zła passa architekta utrzymywała się po odbudowie kościoła oruńskiego. Realizacji nie doczekał się projekt niewielkiego obserwatorium astronomicznego, które miało stanąć na terenie przyłączonej do Gdańska wsi Wrzeszcz $(1818)^{34}$. Podobny los spotkał dwie kolejne propozycje

27 Michaela van der Driesch, Der „gotische Turmaufsatz" der St. Marienkirche in den Akten - ein Beispiel für Architektur und Farbe im Stadtraum Berlin um 1800 [w:] Neue Baukunst. Berlin um 1800, Hg. Elke Blauert, Katharina Wippermann, Berlin 2007, s. 110; Rüsch, Baukonstruktion zwischen Innovation..., s. 134-136.

28 van der Driesch, Der „Gotische Turmaufsatz”..., s. 106.

29 Co więcej, Held konsekwentnie stosując uproszczone formy klasycyzujące, wydawał się przy tym odporny na wpływy zewnętrzne, a jego projekty nie ewoluowały w stronę rozwiązań bardziej nowoczesnych.

30 Krause, Das Danziger Theather..., s. 32.

31 Janusz Dargacz, $Z$ dziejów gdańskich kapielisk. Projekty Carla Samuela Helda dla Jelitkowa $z 1801$ roku [w:] Gdańsk i okolice..., s. 65.

32 Krause, Das Danziger Theather..., s. 39.

33 Friedrich Karl Gottlieb von Duisburg, Versuch einer historisch-topographischen Beschreibung der freien Stadt Dantzig, Dantzig 1809, s. 302.

34 APGd, Kolekcja pomorskich planów i map 1634-1945, sygn. 38/648. 
Magdalena budowy nowego gmachu Gimnazjum Akademickiego, które w wyniku połąStaregga czenia ze Szkołą Mariacką stało się Gimnazjum Miejskim. Zarówno projekt z 1829 r., jak i o rok późniejszy nie uzyskały pozytywnej opinii urzędników Oberbaudeputation.

Ostatecznie Heldowi pozostawiono tylko, jako miejskiemu architektowi, nadzór nad budową kościoła oruńskiego ${ }^{35}$. Odbiór gotowego, trójnawowego kościoła $\mathrm{z}$ dostawioną od frontu wieżą zwieńczoną ostrosłupowym hełmem nastąpił 10 września 1823 r. Była to pierwsza w Gdańsku i okolicach budowla, której nadano cechy neogotyckie ${ }^{36}$ (il. 7). Prosta ceglana bryła kościoła otrzymała stosunkowo oszczędną artykulację. W ścianach bocznych przebito ostrołukowo zamknięte okna, a środkowy otwór w elewacji północnej połączono z dwuskrzydłowymi drzwiami prowadzącymi do nawy bocznej. Elewację wschodnią zwieńczono trójkątnym szczytem z blendami i sterczynami nad linią dachu. Nad portalem zaprojektowano zamknięte ostrołukowo nadświetle z motywem rybich pęcherzy. Znaczącym dopełnieniem stylowego wyrazu budowli było jej wnętrze (il. 8). Trzy pięcioprzęsłowe nawy nakryto drewnianymi sklepieniami gwiaździstymi, które po otynkowaniu imitowały konstrukcję ceglaną. Sklepienia zostały wsparte na czterech parach drewnianych filarów o przekroju sześciobocznym. Na filarach oparto również drewniane empory o płycinowych balustradach, rozmieszczone nad nawami bocznymi, a w części zachodniej kościoła umieszczono chór $\mathrm{z}$ organami $\mathrm{i}^{37}$. Na realizację budowy ostatecznie przyznano środki publiczne w wysokości 15198 talarów ${ }^{38}$.

Mimo zbliżonej formy przedstawione przez Helda propozycje odbudowy kościoła nie miały większego wpływu na ostatecznie zrealizowany projekt, którego powstaniem kierowała od wiosny 1819 r. Wyższa Deputacja Budowlana. W proces powstania projektu było zaangażowanych kilku urzędników. Ogólne wytyczne, korekta przedłożonych planów i zatwierdzenie koncepcji leżały po stronie Karla Friedricha Schinkla ${ }^{39}$. Weryfikował on wszystkie projekty

35 Inwestycję prowadzili mistrzowie budowlani - Daniel Emmanuel König i Johann Christian Halbritter, zob. APGd, KEG, sygn. 977/1139, s. 5 i n.; Waage, Ausführliche Geschichte Ohra's..., s. 131.

36 W dokumentacji używane jest określenie „W stylu staroniemieckim” („im altdeutschen Stil”), zob. APGd, KEG, sygn. 977/1139, s. 154 i n. W okresie powstania gdańskiego gmachu pojęcie staroniemiecki było stosowane w odniesieniu do stylu gotyckiego, zob. Irma Kozina, Aspekty stosowania pojęcia ,historyzm” w badaniach nad architektura niemiecka XIX wieku, „Rocznik Historii Sztuki” 1997, t. 23, s. 143.

7 Więcej a temat wyposażenia kościoła zob. Waage, Ausführliche Geschichte Ohra's..., s. 130. 8 APGd, KEG, sygn. 977/3044, s. 196.

39 APGd, KEG, sygn. 977/1139, s. 208. Zachowane rysunki z odręcznymi poprawkami znajdują się w gdańskim archiwum, zob. APGd, RGPM, sygn. 18/1614, ark. C, oraz w Kupferstichkabinett der Staatlichen Museen zu Berlin, zob. Preußischer Kulturbesitz w Berlinie, sygn. SM 44b.70. Poza Schinklem w dokumentacji pojawiają się nazwiska trzech innych architektów biorących udział w pracach nad projektem: rządowego nadinspektora budowlanego Gottfrieda Steffany (ur. 1774), dyrektora budowlanego Carla Gottlieba Hartmanna (ur. 1774), a także gdańszczanina, inspektora budowlanego Carla Augusta von Gersdorffa (1797-1850). Ten ostatni 


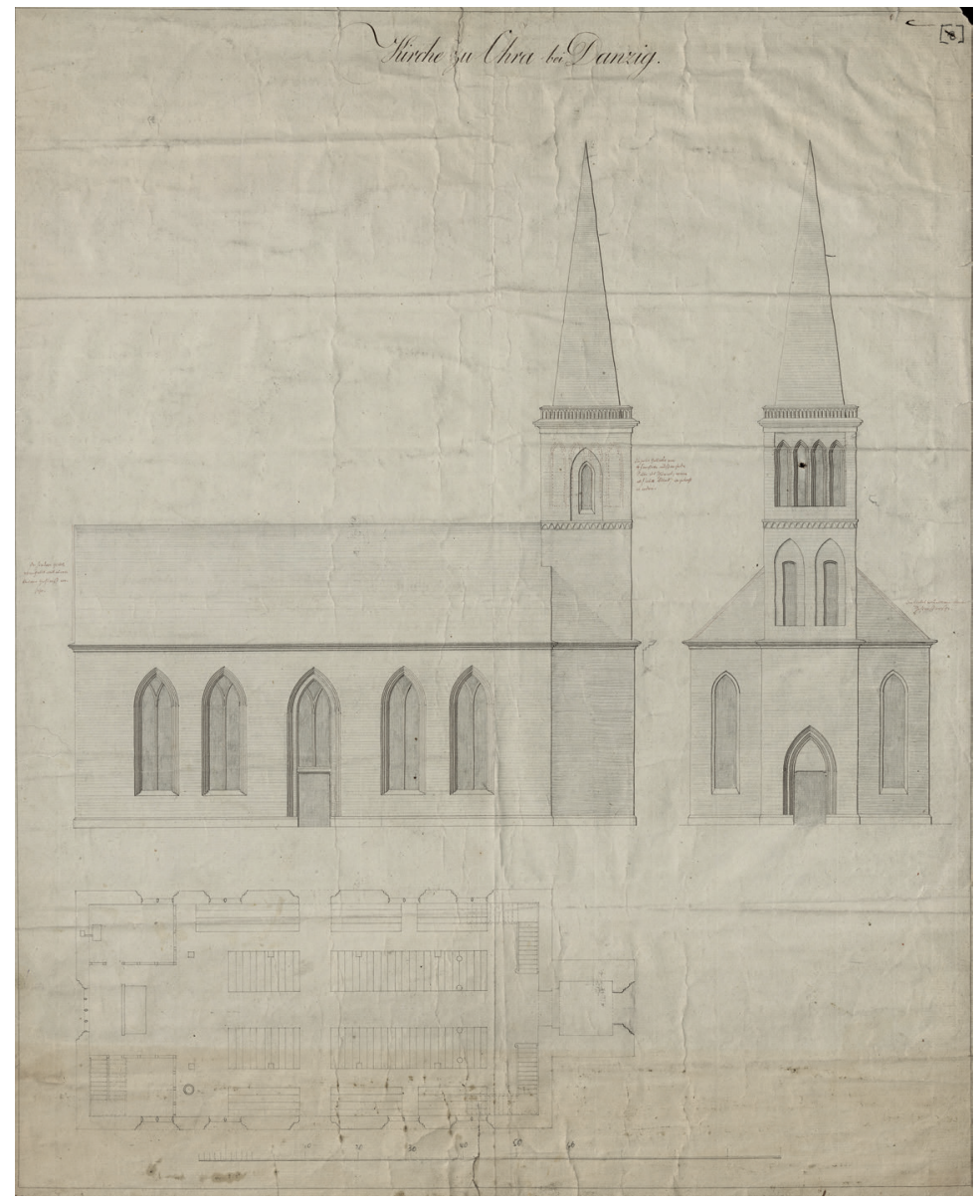

Niezreali-

zowane

projekty...

Il. 7. Karl Friedrich Schinkel, Carl August von Gersdorff, projekt kościoła w Oruni z ostatecznymi poprawkami, październik 1819, APGd, RGPM, sygn. 18/1614, ark. C

architektoniczne, które były realizowane z udziałem środków publicznych. Odrzucanie koncepcji składanych przez lokalnych urzędników i przygotowywanie zupełnie nowych, nierzadko całkowicie odmiennych formalnie, było wówczas częstą praktyką ${ }^{40}$. Tym razem jednak za narzucenie określonego kostiumu

jest wymieniany, m.in. w umowie dotyczącej budowy kościoła, jako autor projektu i kosztorysu inwestycji, zob. APGd, KEG, sygn. 977/1139, s. 208; Börsch-Supan, Karl Friedrich Schinkel..., s. $287-288$.

40 Tendencja ta nie dotyczyła wyłącznie Gdańska. Podważanie kompetencji lokalnych budowniczych i przejmowanie prac nad inwestycjami było bardzo odczuwalne także w innych ośrodkach, zob. Zofia Ostrowska-Kębłowska, Architektura i budownictwo w Poznaniu w latach 1780-1880, Poznań 1982, s. 107, 241; Marian Arszyński, Nowomiejski kościół ewangelicki $w$ Toruniu. Przyczynek do dziejów architektury pierwszej połowy XIX wieku na Pomorzu, „Acta 


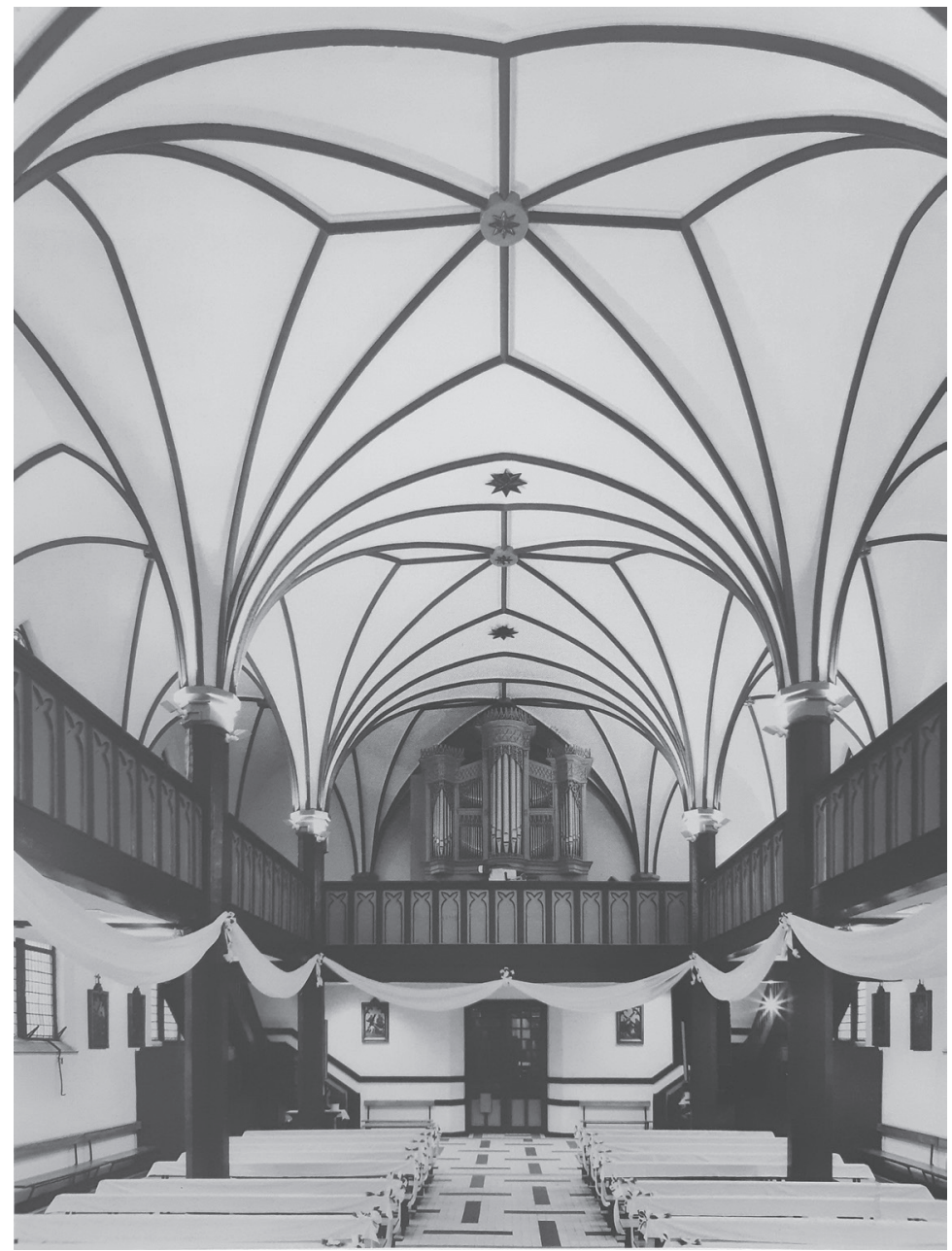

Il. 8. Wnętrze kościoła w Oruni, repr. za: Karl Friedrich Schinkel, Das architektonische Werk heute, Stuttgart-London 2001

stylowego odpowiedzialny był nadprezydent prowincji Prusy Zachodnie, Theodor von Schön (1773-1856), który zgodnie z intencją króla od maja $1818 \mathrm{r}$. procedował dalsze prace nad odbudową kościoła ${ }^{41}$. To na jego życzenie miała powstać budowla $\mathrm{w}$ „stylu staroniemieckim” ${ }^{42}$. Uznanie takich form za obowiązujące dla podgdańskiego kościoła znajduje uzasadnienie w działaniach urzędnika, który od 1815 r. był głównym animatorem prac restauracyjnych zamku

Universitatis Nicolai Copernici. Nauki Humanistyczno-Społeczne. Zabytkoznawstwo i Konserwatorstwo" 1994, t. 25, s. 172-173.

41 APGd, KEG, sygn. 977/3044, s. 46.

${ }^{42}$ Ibidem, s. 93. Za pomoc w interpretacji dokumentu dziękuję Izabeli Brzostowskiej. 
malborskiego ${ }^{43}$. Ideowe nawiązania do Malborka - symbolu ducha niemieckiego, miało szczególne znaczenie w odniesieniu do ziem „odzyskanych” po $1814 \mathrm{r}$. Nie przez przypadek do prac nad projektem zaangażowano współpracującego $\mathrm{z}$ von Schönem Carla Augusta von Gersdorffa, od 1819 r. kierującego odbudową zamku $^{44}$. W prace restauracyjne w Malborku był silnie zaangażowany również sam Schinkel ${ }^{45}$. O ile zwrot ku formom neogotyckim nie był jego pomysłem ${ }^{46}$, o tyle mógł on inspirować zastosowanie konkretnych rozwiązań, takich jak np. sklepienie gwiaździste ${ }^{47}$.

Proces wyłaniania projektu budowli odbywał się w szczególnych okolicznościach. W dniu 27 września 1817 r. na mocy dekretu króla Prus Fryderyka Wilhelma III połączono w jeden kościół dwa odrębne dotąd wyznania - luterańskie i kalwińskie. Stworzenie nowej formuły unifikującej wiernych protestanckich było szczególnie istotne w odniesieniu do ziem przyłączonych do Królestwa Prus po kongresie wiedeńskim. Wyjątkowa rola w tym zakresie przypadła urzędnikom berlińskiej Wyższej Deputacji Budowlanej, dążącej do standaryzacji ewangelickiego budownictwa ${ }^{48}$. Historia budowy oruńskiego kościoła wpisuje się w początkową fazę poszukiwań rozwiązań optymalnych pod względem ekonomicznym, o określonej wymowie ideowej, zmierzających przy tym do silnej centralizacji i ograniczenia roli lokalnych urzędników. Opracowanie wariantów tzw. Normalkirche, dostosowanych do potrzeb gmin wyznaniowych, będzie przez kolejne lata jednym z głównych celów stojącego na czele Oberbaudeputation Schinkla ${ }^{49}$.

43 Więcej o jego udziale zob. Bernhard Schmid, Oberpräsident von Schön und die Marienburg, Halle 1940.

44 Gersdorff kierował pracami rekonstrukcyjnymi malborskiego zamku aż do swojej śmierci, będąc bliskim współpracownikiem nadprezydenta von Schöna. Więcej o karierze urzędnika zob. Schmid, Oberpräsident von Schön..., s. 12-13; Carl August von Gersdorff [w:] Deutsche Biographische Enzyklopädie, Bd. 3, München 2006, s. 787. Informacja o Gersdorffie jako projektancie kościoła oruńskiego została zamieszczona również w monografii Ernsta Wilhelma Waage, Ausführliche Geschichte Ohra's..., s. 124.

45 Börsch-Supan, Karl Friedrich Schinkel..., s. 288-289, 539-616.

46 Decydującą w tym zakresie rolę von Schöna potwierdzają ówczesne zainteresowania Schinkla. W owym czasie jego fascynacja gotykiem zdaje się słabnąć na rzecz form klasycystycznych, a także zupełnie nowego zespołu środków w postaci Rundbogenstilu. Odbiciem tych tendencji są m.in. projekty kościoła katolickiego w Kwidzynie (1820) oraz kościołów ewangelickich w Toruniu (1818) czy Hemer (1818). Trafna wydaje się więc hipoteza zakładająca, że gdyby nie sugestia von Schöna, Schinkel wykorzystałby tę okazję do stworzenia kolejnego projektu w zgodzie ze swoimi aktualnymi preferencjami estetycznymi, zob. Arszyński, Nowomiejski kościót ewangelicki..., s. 177-180.

47 W kontekście udziału Schinkla w projektowaniu budowli związki te dostrzega Jacek Friedrich, Walka obrazów. Przedstawienia wobec idei w Wolnym Mieście Gdańsku, Gdańsk 2018, s. 29.

48 Więcej na ten temat zob. Piotr Birecki, Ewangelickie budownictwo kościelne w Prusach Zachodnich. Relacje między państwem a Kościołem ewangelicko-unijnym, Toruń 2014, s. 49-76.

49 Pierwszy projekt kościoła wzorcowego zatwierdzony przez króla powstał w $1827 \mathrm{r}$. Więcej na temat udziału Schinkla w projektowaniu budownictwa sakralnego zob. Börsch-Supan, Karl Friedrich Schinkel..., s. 232-522. 

doczekały się realizacji, stanowią ciekawy przykład formowania lokalnej architektury przez administrację zwierzchnią. Za najbardziej znany przykład tego typu działań na gruncie gdańskim można uznać ingerencję następcy tronu, późniejszego króla Fryderyka Wilhelma IV, w formę Gimnazjum Miejskiego. Wstrzymanie w $1834 \mathrm{r}$. budowy klasycystycznego gmachu i narzucenie mu form „staroniemieckich" miało być wyrazem nowej przynależności państwowej ${ }^{50}$. Można uznać, że nadprezydentowi von Schönowi, mocno zaangażowanemu w prace restauracyjne przy pomniku niemieckości w tej części Prus, przyświecały podobne przesłanki. Ponownie dojdą one do głosu w 1841 r., kiedy za wzór dla przebudowywanej Sali Wety w ratuszu Głównego Miasta posłuży letni refektarz pałacu wielkich mistrzów zamku malborskiego ${ }^{51}$.

Kościół oruński szczęśliwie przetrwał zawieruchę ostatniej wojny. Stanowi najstarszy $\mathrm{i}$ jeden $\mathrm{z}$ najcenniejszych neogotyckich zabytków miasta. W powszechnej opinii uchodzi on jednoznacznie za dzieło Schinkla. Ufam, że spostrzeżenia i uwagi poczynione w niniejszym artykule pozwolą nie tylko na lepsze poznanie okoliczności powstania kościoła, lecz także - poprzez zobrazowanie relacji pomiędzy lokalnym urzędnikiem w postaci miejskiego radcy budowlanego a urzędem centralnym - zwrócą uwagę na działanie pruskiej administracji budowlanej w kontekście Gdańska.

\section{Bibliografia}

Arszyński Marian, Nowomiejski kościół ewangelicki w Toruniu. Przyczynek do dziejów architektury pierwszej połowy XIX wieku na Pomorzu, „Acta Universitatis Nicolai Copernici. Nauki Humanistyczno-Społeczne. Zabytkoznawstwo i Konserwatorstwo" 1994, t. 25, s. 172-173.

Bielak Jacek, Budowniczy miejski Carl Samuel Held i próby modernizacji Gdańska na przełomie XVIII/XIX wieku [w:] Gdańsk i okolice 1793-1914. Miasto - ludzie - wydarzenia w rysunku i grafice, red. Wojciech Bonisławski, Aleksander Baliński, Gdańsk 2014, s. 54-63.

Bielak Jacek, Städtisch oder staatlich? Das Danziger Städtische Gymnasium in den Jahren 1835-1837 [w:] Stadtkultur des späten Mittelalters und der frühen Neuzeit in Ostmitteleuropa und ihre Renaisance im 19. Jahrhundert / Kultura miast środkowo$i$ wschodnioeuropejskich w późnym średniowieczu i renesansie oraz jej odrodzenie w XIX wieku, red. Marco Bogade, Warszawa 2012, s. 229-242.

50 Więcej na ten temat zob. Jacek Bielak, Städtisch oder staatlich? Das Danziger Städtische Gymnasium in den Jahren 1835-1837 [w:] Stadtkultur des späten Mittelalters und der frühen Neuzeit in Ostmitteleuropa und ihre Renaisance im 19. Jahrhundert / Kultura miast środkowo- $i$ wschodnioeuropejskich w późnym średniowieczu i renesansie oraz jej odrodzenie w XIX wieku, red. Marco Bogade, Warszawa 2012, s. 229-242; idem, Tradycjonalizm w stużbie państwa..., s. 87-117.

${ }_{51}$ Autorem projektu przebudowy był ponownie Gersdorff, zob. Bernhard Schmid, Die Denkmalpflege in Westpreussen 1804-1910, Danzig 1910, s. 19. 
Bielak Jacek, Tradycjonalizm w służbie państwa. Szkic z dziejów nowego gmachu Gdańskiego Gimnazjum Akademickiego [w:] Tradycjonalizm i neotradycjonalizm w sztuce XIX i XX wieku na Pomorzu, red. Józef Tarnowski, Roman Nieczyporowski, Gdańsk 2012, s. 87-117.

Birecki Piotr, Ewangelickie budownictwo kościelne w Prusach Zachodnich. Relacje między państwem a Kościołem ewangelicko-unijnym, Torun 2014.

Börsch-Supan Eva, Karl Friedrich Schinkel. Die Provinzen Ost- und Westpreußen und Großherzogtum Posen, München-Berlin 2003.

Dargacz Janusz, Z dziejów gdańskich kąpielisk. Projekty Carla Samuela Helda dla Jelitkowa z 1801 roku [w:] Gdańsk i okolice 1793-1914. Miasto - ludzie - wydarzenia w rysunku i grafice, red. Wojciech Bonisławski, Aleksander Baliński, Gdańsk 2014, s. 65-70.

Driesch Michaela van der, Der „Gotische Turmaufsatz” der St. Maarienkirche in den Akten - ein Beispiel für Architektur und Fabre im Stadtraum Berlin um 1800 [w:] Neue Baukunst. Berlin um 1800, Hg. Elke Blauert, Katharina Wippermann, Berlin 2007, s. 105-115.

Friedrich Jacek, Walka obrazów. Przedstawienia wobec idei w Wolnym Mieście Gdańsku, Gdańsk 2018.

Grundmann Friedhelm, Carl Gotthard Langhans (1732-1808). Lebensbild und Architekturführer, Würzburg 2007.

Harnoch Agathon, Chronik und Statistik der evangelischen Kirchen in den Provinzen Ost- und Westpreussen, Neidenburg 1890.

Hinrichs Walther Th., Carl Gotthard Langhans. Ein schlesischer Baumeister 1733-1808, Strassburg 1909.

Keyser Erich, Die Baugeschichte der Stadt Danzig, Köln-Wien 1972.

Kos Jerzy Krzysztof, Carl Gotthard Langhans 1732-1808. Architekt z Kamiennej Góry, Kamienna Góra 2007.

Kos Jerzy Krzysztof, Der Weg nach Berlin... Carl Gotthard Langhans' Tätigkeit in Schlesien 1760-1808 [w:] Deutsche Baukunst um 1800, Hg. Reinhard Wegner, Köln 2000, s. 65-92.

Kozina Irma, Aspekty stosowania pojęcia „historyzm” w badaniach nad architektura niemiecka XIX wieku, „Rocznik Historii Sztuki” 1997, t. 23, s. 171-182.

Kozina Irma, Styl około 1800. Styl narodowy czy nowa rzeczywistość $w$ architekturze Górnego Śląska? [w:] Nacjonalizm w sztuce i historii sztuki 1789-1950, red. Dariusz Konstantynów, Robert Pasieczny, Piotr Paszkiewicz, Warszawa 1998, s. 171-182.

Krause Waldemar, Das Danziger Theather und sein Erbauer Carl Samuel Held, Danzig 1936.

Maciakowska Zofia, Szymański Wojciech, Akta Policji Budowlanej jako materiał do studiów nad gdańską kamienica mieszczańską od średniowiecza do początku XIX wieku [w:] Dom w mieście średniowiecznym i nowożytnym, red. Bogusław Gediga, Wrocław 2004, s. 249-276.

Maciakowska Zofia, Szymański Wojciech, Dokumentacja Urzędu Policji Budowlanej w Gdańsku jako źródło do badań nad dawnymi kamienicami [w:] Studia i materiały do dziejów domu gdańskiego, cz. 1, red. Edmund Kizik, Gdańsk 2009, s. 207-223.

Mebes Paul, Um. 1800. Architektur und Handwerk im letzten Jahrhundert ihrer traditionellen Entwicklung, München 1908.

Muhl John, Die Kirche und Schule in Ohra, „Weichselland” 1942, No. 41, s. 40-45.

Ostrowska-Kębłowska Zofia, Architektura i budownictwo w Poznaniu w latach 1780-1880, Poznań 1982. 

2000, s. 109-128.

Rüsch Eckart, Baukonstruktion zwischen Innovation und Scheiter. Verona, Langhans, Gilly und die Bohlendacher um 1800, Petersberg 1997.

Samp Jerzy, Orunia, Stare Szkoty i Lipce, Gdańsk 2005.

Schmid Bernhard, Die Denkmalpflege in Westpreussen 1804-1910, Danzig 1910.

Schmid Bernhard, Oberpräsident von Schön und die Marienburg, Halle 1940.

Velin Regulus, Der Baumeister des Brandenburger Tores. Historiographisches über den Architekten Carl Gotthard Langhans, Berlin 1983.

Waage Ernst Wilhelm, Ausführliche Geschichte Ohra's eines Dorfes im Danziger Landraths-Kreise, Regierungsbezirks Danzig, Danzig 1859.

Wessel Max, Die Organisation der Polizei in der Stadt Danzig und in ihrem Hafen nach Einverleibung derselben in die preußische Monarchie, Danzig 1905.

\section{Unrealized Reconstruction Projects of the Church in Orunia by Carl Samuel Held, the Municipal Architect of Gdańsk}

This article discusses widely unknown designs of the Evangelical church in the village of Orunia near Gdańsk from 1816-1819. The concepts preserved in the State Archive in Gdańsk contain as many as eight variants of the reconstruction of the meeting house destroyed during a siege in 1813 . The author of these concepts was the contemporary city architect Carl Samuel Held. As a student of Carl Gotthard Langhans (1732-1808), one of the greatest Prussian architects of that time, Held consistently used classicist forms throughout his body of work. His first two designs for the reconstruction of the church in question were in line with the so-called revolutionary classicism. The following six neo-Gothic variants constituted a formal exception in his oeuvre. Moreover, the case of the Orunia church was the only time he ever attempted to design a sacral building. The clumsiness in the use of neo-Gothic forms, as well as the inability to fit into the assumed financial framework contributed to the rejection of Held's designs. Eventually, the project by August von Gersdorff verified by the head of the Higher Construction Deputy Karl Friedrich Schinkel was the one that was implemented. The construction was completed in 1823. The forms used in the building exhibit inspiration drawn from the Teutonic castle in Malbork. The prime mover behind their use was the Oberpräsident of the Province of West Prussia Theodor von Schön, promoter of the restoration work at the castle. The church in Orunia is the first case of a building with neo-Gothic features in Gdańsk and its area, as well as the first construction with forms intentionally referring to the Malbork Castle, a landmark symbolizing the essence of Germanity. 